\title{
Governing Globalization. The Challenge of Protectionism to Multilateralism
}

\author{
Lucio Levi
}

It seemed that the world had overcome the storm of the global financial and economic crisis of 2007-2008 without repeating the mistakes of the past, first of all protectionism that, in the inter-war period, brought about the collapse of the volume of world trade and destroyed millions of jobs. Instead, now that the EU and the US have taken a step forward towards economic recovery Mario Draghi has warned that growth is threatened by two factors that can be ascribed to the American government - protectionist policies and the weakening of the dollar - aiming to gain competitiveness on international markets. The memory of the crisis of 1929 has not been a sufficient warning to stop Trump. The globalization process, based on the principles of multilateralism and open markets, as we have known it in the past years, is at risk.

From 1948, when the GATT was created, to 1990 the growth of world trade has been close to $7 \%$ per year, quicker than in the following years that we are used to consider the golden age of globalization. At the same time, the custom tariffs, that in 1946 amounted to $50 \%$ of the value of imported goods, today have dropped to about 3\%. The enlargement of market dimension and the expansion of trade relations brought about by globalization has represented a powerful driving force of growth of world economy. It has promoted the industrialization, formerly limited to Western Europe and North America, to the rest of the world. The traditional centreperiphery relations are becoming obsolete and the centre of gravity of world economy has shifted from the Atlantic to the Pacific. The per capita revenue in the emerging countries has increased impetuously. According to the data provided by the World Bank, the percentage of world population living in conditions of extreme poverty (US\$ 1.90 per day), which in 1990 amounted to $37.1 \%$, in 2015 has been reduced to $9.6 \%$ and is concentrated in SubSaharan Africa and South Asia.

At the same time, globalization has had highly asymmetric effects, as the gap between rich and poor people has significantly widened. This is because globalization is not governed, but is abandoned to the free play of market forces. Deregulation has not produced the results expected by the ideology of the selfregulated market. Institutions and rules are necessary to oblige market to behave in a way that benefits all. For this reason, politics returns to take the stage. The alternative is no longer between supporters and opposers of globalization, but between different ways to react to the distortions of globalization.

It is not true that everybody benefits from free trade. Protectionism is a policy largely adopted by the developing countries to be prepared to compete in international markets. It was adopted for the first time by the United States at the end of the $18^{\text {th }}$ century to enable the American infant industries to compete with the British industry, then by Germany and Japan at the end of $19^{\text {th }}$ century, lastly by China and India at the end of the $20^{\text {th }}$ century. In the last century, when the centre of the economic and political power shifted from London to Washington and New York, the United States became, like formerly the British Empire, a promoter of international 
free trade, the vehicle to assert its political, economic and technological superiority. Today that it is a declining power, the United States defends with protectionism what remains of its predominance.

Owing to their regional dimension, China and India are the developing countries that have benefited the most from protectionism. Connectivity is a cornerstone for regional economic integration through infrastructure networks of trade, transport, ICT, energy. Instead, owing to its fragmentation into 55 member states, the African Union is the most backward regional organization of the world. It is significant that in the very days when Trump ordered new tariffs, the creation of an African free trade area has been promoted by 49 member states. It represents an initiative going against the tide, as it entails the commitment to eliminate tariffs barriers on $90 \%$ of the exchanges among African countries. It is the largest trade agreement since the creation of the WTO and develops on the wake of the model of the EU. It can play the role of driving force of the development of Africa through multilateral cooperation between all the states of the continent and the creation of an independent industrial structure.

A defense of the arguments in favour of protectionism has been proposed by two authors whose thought is linked to federalism: Alexander Hamilton, the theorist of the American protectionism, and Friedrich List of the German one. The first was one of the Founding Fathers of the United States of America, the second reached the conclusion that the contradiction between the interests of free-traders and those of protectionists could be overcome only within the framework of a world federal order. Both of them have pointed out that the organization of the world into sovereign states - and the implicit strength relations and conflicts of interest - prevent trade exchanges from occurring in conditions of equality. If the United States and Germany wanted to avoid underdevelopment, only protectionism would have enabled the newlyborn industries of those countries to compete with the British ones. For the same reasons the WTO has provided a differentiated treatment between emerging and developed countries. But, on the whole, those agreements have not penalized the US, which was entitled to provide high subsidies to agriculture. The application of the principles of full reciprocity and total symmetry in the rules of international trade would not offer an equitable solution. It would penalize the developing countries. In fact, it is not easy to define equitable rules when the gap between developed and developing countries is too wide. The per capita revenue in China is still one fifth of that of the US, therefore a differentiated treatment is justified.

But once the most backward countries have emerged from underdevelopment, the problem that remains to be solved is the peaceful coexistence between states. List asserted that "The highest association of individuals now realized is that of the state, the nation; and the highest imaginable is that of the whole human race". Therefore, "If we assume ... a universal association or federation of all nations as a guarantee of perpetual peace, the principle of free trade among nations would be fully established". As World Federation is a distant ultimate goal, the problem that the contemporary man has to address is the definition of the stages of the transition towards that target. The starting point for facing the need for regulating mechanisms of market unbalances and distortions is empowering international institutions. The GATT with the most favoured nation clause and the WTO with its dispute settlement body have provided an embyonic regulation for global markets. The progressive answer to those who dream that the right way is entrenching themselves behind national borders is strengthening and democratizing the WTO. The EU's institutions show the way to follow. 